\title{
Implementation of Five C's Marketing Analysis at the Alia Sport Indonesia Entrepreneurship Start-Up
}

\author{
Teddy Siswanto* \\ Information System Department \\ Trisakti University \\ Jakarta, Indonesia \\ *teddysiswanto@ trisakti.ac.id \\ Ratna Shofiati \\ Informatics Department \\ Trisakti University \\ Jakarta, Indonesia
}

\author{
Wawan Kurniawan \\ Industrial Technical Department \\ Trisakti University \\ Jakarta, Indonesia \\ Hartini Hartini \\ Management Department \\ Trisakti University \\ Jakarta, Indonesia
}

\author{
Rahman Nur Hidayat \\ Accounting Department \\ Trisakti University \\ Jakarta, Indonesia
}

\begin{abstract}
Starting as a Futsal sports athlete, Rahman, a Trisakti University student, founded a business making $T$-shirts with the Alia brand. The production process of making shirts based on orders is done at his Bekasi area. Problems encountered are related to financial management and sales that are not yet stable. The methodology used in analysing the problems faced by Alia's tenants uses The Five C's Marketing Analysis consisting of Customers, Company Skills, Competitors, Collaborators and Context. The solutions produced in the analysis have been carried out by tenants in fixing existing problems so that financial management can be easily done and increased sales through information technology.
\end{abstract}

Keywords: jersey shirt, financial management, sales, entrepreneurship, Five C's Marketing Analysis

\section{INTRODUCTION}

Futsal sports have become a routine activity in daily life for a student of the Faculty of Economics and Business at Trisakti University named Rahman, so it occurred to him to be an entrepreneur selling futsal sports equipment. Starting with the sale of hats, T-shirts and polyflex screen printing services, the start-up stands under the name Alia Custom on January 10, 2016. Sales are conducted using the conventional method of mouth to mouth or from friend to friend. In 2017 this start-up takes care of a business license in the form of a CV and the specific products sold focus on sports products such as soccer jersey, futsal, badminton and basketball so that the name of the business venture is changed to Alia Sport Indonesia. Sales continue to run but the turnover development has not been as expected and in early 2018 the entrepreneur became a tenant of entrepreneurial students in the Entrepreneurship Development Program (PPK) of Trisakti University in the 2018-2019 period.

From the results of the initial analysis, the main problem is that sales promotions are less pro-active and less sustainable because there are still many mouth-to-mouth promotion methods and lack of business capital so that sales have not been stable, waiting for payments from consumers in advance to be able to produce again. These problems must be further analysed as a whole by the Five C's Marketing Analysis method and adopting information technology to improve financial management.

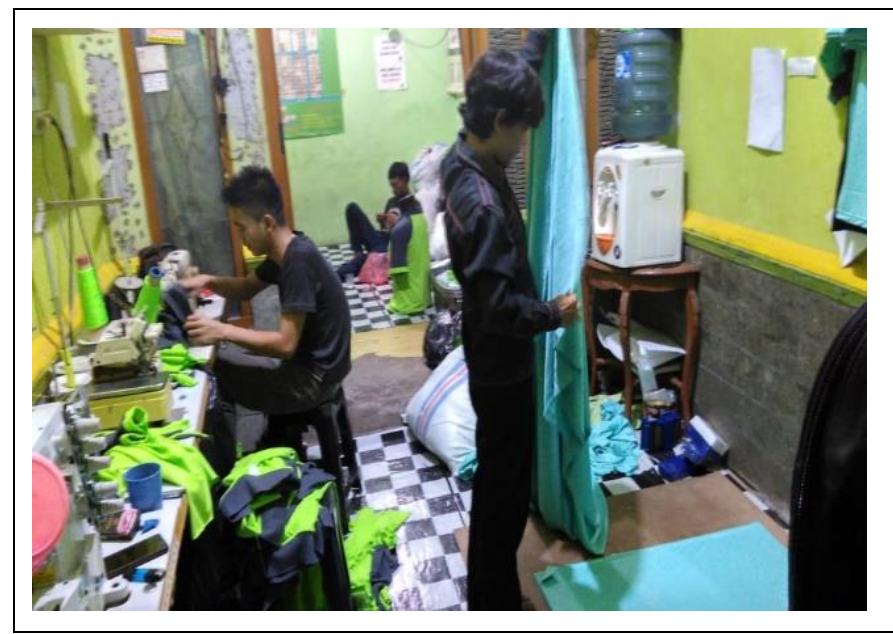

Fig. 1. Production process at Alia Sport.

The resulting output is a web-based company profile application and uses an android-based application for sales data 
competitors 'motivations and strategies so that they can anticipate possible competitors' reactions to new competition.

Playstore and not paid.

\section{IMPLEMENTATION AND METHODS}

To further analyse the problems faced by tenants, Five C'S Marketing Analysis is used to find the root of the problem and find the right solution. Five C'S Marketing Analysis consists of: Customers, Company, Competitors, Collaborators and Context [1] as shown in Figure 2.

\section{Marketing Analysis (The Five C's)}

CUSTOMERS COMPANY COMPETITORS COLLABORATORS CONTEXT

Fig. 2. Marketing analysis.

\section{A. Customers}

What consumer needs do you want to meet in business? It is important to know the specific market that requires the product or service offered. However, this is not enough. In addition to carefully understanding the needs of your customers, an in-depth analysis of customer usage patterns and purchasing decisions is also needed for effective marketing [2]. Keep in mind that purchasing decisions are often a collaborative process and not solely at the user's discretion. Researchers have identified the exact role involved in the buying process. These roles include the initiator, determinant, influencer, buyer, and user. While an individual can occupy some or all of these roles, this is not always the case. For example, the final decision to buy an office desktop might be made by the company's CFO, but the real users will become company employees. Furthermore, the company's IT department is likely to influence the decision. In addition to the purchasing process, the customer's decision making process must also be understood [3]. Consideration is not limited to, is the customer looking for information before making a purchase, and if so, in what way? What criteria do customers use in evaluating alternatives? So it must understand all aspects of the customer's process to evaluate and buy, as well as how the product or service fits into that process.

\section{B. Company Skills}

What special competencies does the company have to meet customer needs? Marketing analysis must include an honest assessment of the strengths and weaknesses of a business [4]. Considerations must include the company's financial footing, production capabilities, and other assets such as skills, expertise and knowledge.

\section{Competitor}

Who is competing with the company in meeting consumer needs? Competitors include not only those currently on the market, but future competitors either in the form of new entrants to the market or substitute offers [5]. We must assess the strengths and weaknesses of these competitors to better determine how to differentiate start-ups in the eyes of consumers. In addition, marketing analysis must address

\section{Collaborator}

Who can work with and accompany the company and how can they motivate? Collaborators include upstream suppliers and downstream distributors [6]. Developing strategies to get support from industry collaborators requires a thorough knowledge of collaborator cost structures, margin expectations, and relationships with competing companies.

\section{E. Context}

Are there cultural, technical and/or legal factors that limit start-up choices? We must understand the environment in which the business will operate. This context includes macroeconomic factors such as the political and regulatory environment, the economic environment, the social and cultural environment, and the technological environment.

\section{RESULTS AND DISCUSSION}

\section{A. Customer}

The target consumers are children, adolescents and adults who love sports especially Futsal because the tenants are in the sport environment. The choice of the target consumer is right and to approach the consumer an approach using social media is:

- Instagram https://www.instagram.com/aliajersey.id/

- Facebook at https://www.facebook.com/pg/cv.aliaeshanindonesia/a bout/

- YouTube at: https://www.youtube.com/watch?v=_IFi5VM-iKI

- Web Blog at http://alia-jersey.blogspot.com/

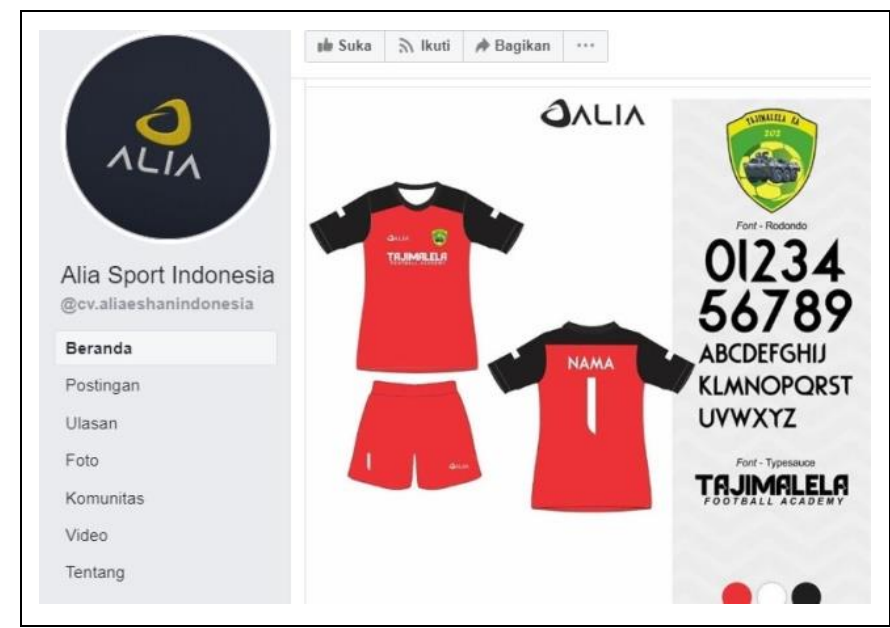

Fig. 3. Alia Facebook.

Social Media has the pro-active advantage of approaching consumers through the delivery of information, but the information conveyed is not deep enough and cannot record 


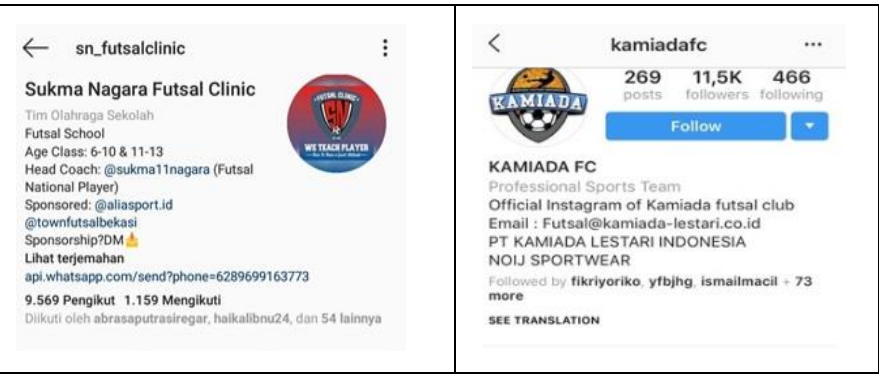

Fig. 5. Marketing collaborators in Jakarta.

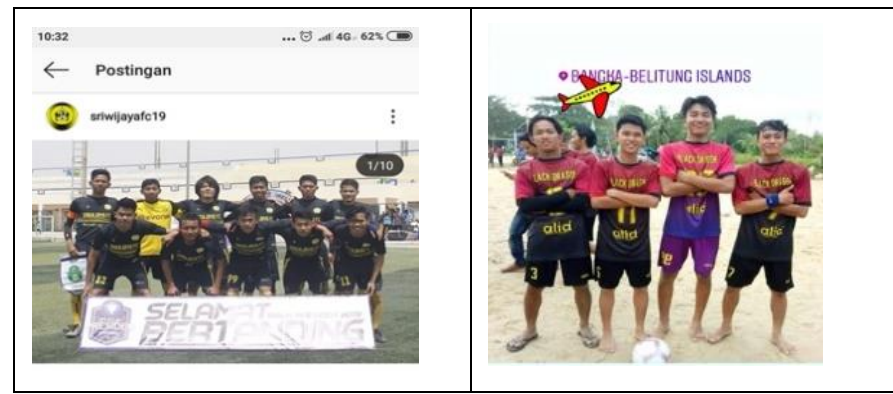

Fig. 6. Marketing collaborators in Palembang and Bangka Belitung.

\section{E. Context}

There are no restrictions on cultural, technical, and / or legal factors in the selection of start-up fields. The activity environment actually supports business development in the field of sports. The development and advancement of information technology has greatly helped the tenant's operational management, including:

1) CCTV: Very helpful in observing the production process because tenants do not have to supervise employees working in the business, can be controlled from outside the city.

2) Paper.id application: The characteristics of this software can be accessed mobile via mobile gadgets and it's free. The features of this tool are [7]:

- Digital Payment

- Invoice Template

- Send an Invoice

- Accounting

- $\quad$ Sales Invoice

- Invoice Reminder

- Inventory

- Expense Tracker

- Financial Statements

- One Click Share

After being implemented by tenants, the following outputs can be generated: with personal around Jakarta and in the regions are created, including: 
With images you can easily read which products are in

$<\quad$ Laporan Laba \& Rugi

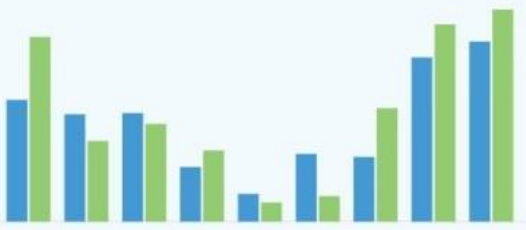

Jan Feb Mar Apr May Jun Jul Aug Sept Okt Nov Dec

Rugi Laba

2019

Jan Laba Rp. $20,785,415$

$\begin{array}{lll}\text { Feb } & \text { Rugi } & \text { Rp.827,237 }\end{array}$

Mar Rugi Rp. $3,576,380$

Apr Laba Rp. 5,460,000

$\begin{array}{lll}\text { May } & \text { Rugi } & \text { Rp. } 2,853,900\end{array}$

Jun Rugi Rp. 13,947,104

Jul Laba Rp. 16,095,798

Aug Laba Rp. 10,923,149

Sep Laba Rp. 10,585,915

Fig. 7. Monthly profit and loss report.

Figure 7 can easily read how the monthly performance is profit or loss.

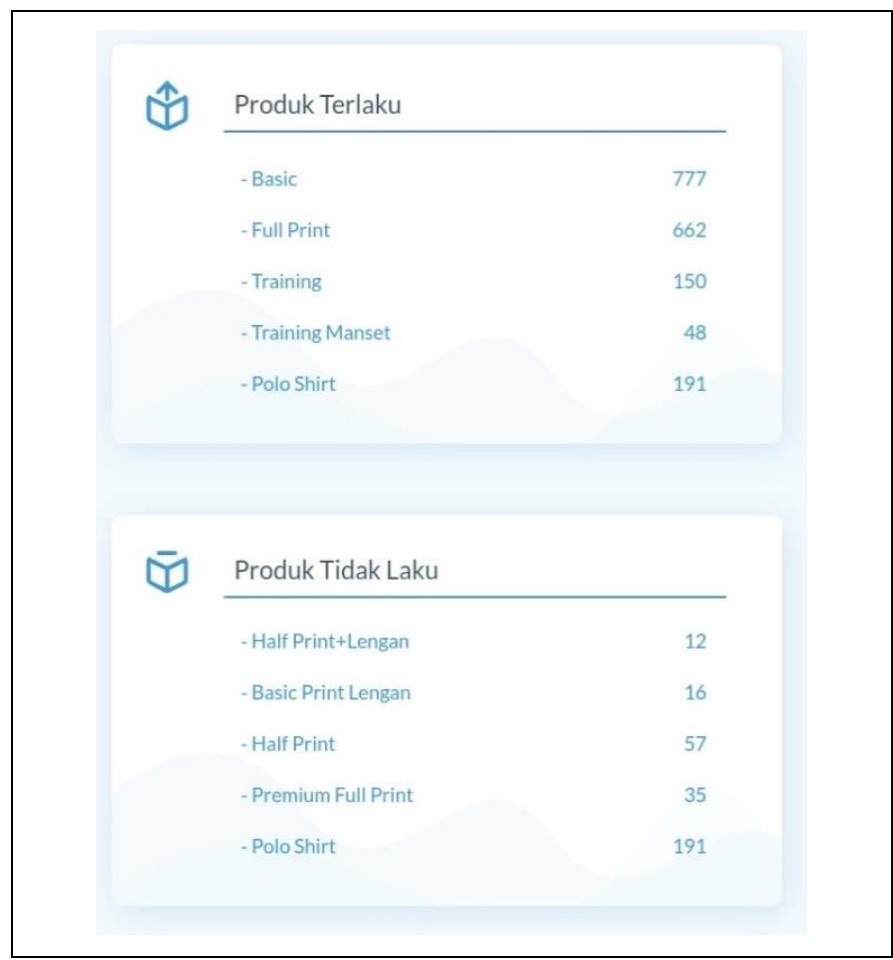

Fig. 8. Salable and non-salable products. demand and are not in demand by consumers.

\section{CONCLUSION}

From the results and previous discussions, it can be concluded and suggested as follows.

- Problems related to marketing, it is correct to use a way to expand the marketing network of futsal clubs in Jakarta and outside the city so that the potential for selling is higher despite having to share profits.

- $\quad$ The use of social media must continue because social media has pro-active characteristics to approach potential consumers through the latest information. However, because social media has shortcomings in terms of in-depth information, it needs to be combined with the useful Paper.id application to record sales transactions.

Suggestion: Utilization of information technology needs to be continued by conducting data collection in real time.

\section{ACKNOWLEDGMENT}

Thank you to Kemeristekdikti who provided the FTI Entrepreneurship Development Program Trisakti University 2017-2019 period.

\section{REFERENCES}

[1] C. Ehmke, J. Fulton, and J. Lusk, Marketing four P's: First steps for new enterpreneurs, 2013. [Online] From URL: http://www.extension.purdue.edu/extmedia/ec/ec730.pdf . Accessed 10 Oct 2019.

[2] C. Grönroos, "Marketing services: the case of a missing product," Journal of business \& industrial marketing, 1998.

[3] E. Constantinides, "Influencing the online consumer's behavior: the Web experience," Internet research, 2004.

[4] H.H. Stevenson, "Defining corporate strengths and weaknesses," Sloan Management Review, vol. 17, no. 3, pp. 51, 1976.

[5] M.A. Peteraf and M.E. Bergen, "Scanning dynamic competitive landscapes: a market-based and resource-based framework," Strategic management journal, vol. 24, no. 10, pp. 1027-1041, 2003.

[6] H.S. Moharana, J.S. Murty, S.K. Senapati, and K. Khuntia, "Coordination, collaboration and integration for supply chain management," International Journal of Interscience Management Review, vol. 2, no. 2, pp. 46-50, 2012.

[7] Paper.id, Prosedur Digital Payment, 2019. Accessed 20 Oct 2019. 